\title{
The Fiduciary Duty of Former Government Employees
}

A former White House adviser becomes a consultant to foreign businesses, using information gained from official involvement in secret international trade negotiations. ${ }^{1}$ A military officer from the Pentagon resigns and goes to work for a munitions manufacturer for whom he then renegotiates a government contract on the basis of confidential government information..$^{2}$ An accountant, formerly with the Treasury Department, advises an investing institution to buy government securities because he knows that the terms of future government offerings, as yet unreleased, will drive up the market price of outstanding government securities. ${ }^{3}$

In each of these cases, confidential federal government information is the basis for personal profit by former government employees. ${ }^{4}$ This exploitation of unequal access to government information frustrates important public concerns: the efficient operation of government programs, the absence of special advantages for certain private

1. Cf. Kwitny, Richard V. Allen Used White House Prestige Freely in Nixon Years, Wall St. J., Oct. 28, 1980, at 1, col. I (White House official allegedly leaked secret information about U.S. export-import policies to Japanese business associate close to Japanese government leaders; after leaving office, same official and associate received consulting contracts from Japanese).

2. Cf. Burnham, Ex-U.S. Aide, Now on Other Side, Stirs Conflicts Issue, N.Y. Times, May 10, 1976, at 55, col. 1 (former HUD official obtained modifications for client in contract official had worked on while at HUD).

3. See In re Blyth \&: Co., 43 S.E.C. 1037, $1038-39$ (1969) (broker-dealer traded in government securities on basis of nonpublic information obtained from Federal Reserve Bank employee).

4. Abuses by former government lawyers are also possible. See, e.g., Allied Realty of St. Paul, Inc. v. Exchange Nat'l Bank, 283 F. Supp. 464 (D. Minn. 1968), aff'd, 408 F.2d 1099 (8th Cir.), cert. denied, 396 U.S. 823 (1969) (former Assistant United States Attorney disqualified from taking position in civil litigation because of official involvement in related criminal matter); Hilo Metals Co. v. Learner Co., 258 F. Supp. 23 (D. Hawaii 1966) (plaintiff's counsel in antitrust case disqualified for having worked on substance of same case while in Department of Justice Antitrust Division); Empire Linotype School, Inc. v. United States, 143 F. Supp. 627 (S.D.N.Y. 1956) (attorney who had passed on contracts while with Veterans' Administration barred from representing those contractors against United States). This Note will focus on public servants other than lawyers because lawyers are already subject to an ethical canon, which covers part of the scope of the rules for government employees that this Note will propose. See ABA Code of Professional Responsibility, Disciplinary Rule 9-101(B) (1979) [Disciplinary Rules hereinafter cited as DR without cross-reference] ("A lawyer shall not accept private employment in a matter in which he had substantial responsibility while he was a public employee.") This Nate's analysis would still apply to lawyers, however, insofar as certain conduct not proscribed by professional ethics may contravene the principles defined in this Note. 
groups, and the maintenance of the integrity of and public confidence in government. Yet current law does not solve the problem. ${ }^{5}$ The only government-wide attempt to restrict the activities of former employees, Title $V$ of the Ethics in Government Act of $1978,{ }^{\circ}$ applies only to federal executive-branch officials and is limited to contacts by those officials with their former agencies. Moreover, the statute is concerned primarily with the narrow issue of undue influence. It thus fails to address in any comprehensive manner the broader problem of the misuse of confidential information obtained while in public employment.

This Note argues that the federal government should supplement Title $\mathrm{V}$ by enforcing the fiduciary duty of its former employees, a duty that requires those employees to keep confidential government information confidential. ${ }^{7}$ This approach to the problem possesses

5. The inadequacy of the law does not mean that Congress has been unaware of the problem. See, e.g., Ethics and Financial Disclosure: Hearings on H.R. 3829 Before the Subcomm. on Employee Ethics and Utilization of the House Comm. on Post Office and Civil Service, 95th Cong., Ist Sess. $72-75$ (1977) (comments of Congressman Floyd J. Fithian) (discussing problem of former public servants helping private employers "avoid compliance" with federal regulations); Federal Ethics and Financial Disclosure: Hearings on H.R. 6954, H.R. 2733, and H.R. 3928 Before the Subcomm. on Employee Ethics and Utilization of the House Comm. on Post Office and Civil Service, 95th Cong., Ist Sess. 56-57 (1977) (statement of Congressman Benjamin S. Rosenthal) (discussing failure of Ethics in Government Act predecessor to restrict former government employees' use of government information); Financial Disclosure Act: Hearings on H.R. 1, H.R. 9, H.R. 6954, and Companion Bills Before the Subcomm. on Administrative Law and Governmental Relations of the House Comm. on the Judiciary, 95th Cong., 1st Sess. 563-64 (1977) (testimony of Thomas H. Henderson, Jr., Chief, Public Integrity Section, Criminal Division, Department of Justice) (discussing hypothetical case of former Justice Department attorney) [hereinafter cited as Disclosure Act Hearings].

Professional and academic lawyers have also suggested ways to prevent the misuse of government information. See Special Committee on the federal Conflict of Interest Laws, Association of the Bar of the City of New YoRK, Conflict of INTERest AND FEDERAL SERvice 223-35, 246, 292-94, 303 (1960) (use of confidential information presents conflict of interest and should be remedied by recovery of treble profits); Kalo, Delerring Use of Confidential Government Information: A Proposed Citizens' Action, $72 \mathrm{M}$ McH. L. REv. 1577 (1974) (urging that citizens be allowed to sue former and present public employees on government's behalf to recover profits gained by use of confidential government information); cf. Flaum \& Carr, The Equitable Bill of Accounting-A Viable Remedy for Combatting Official Misconduct, 62 ILL. B.J. 622 (1974) (recommending equity suits against state officials for breach of fiduciary duty, particularly for misappropriation of public funds).

For lawyers, DR 9-10I(B) of the ABA Code of Professional Responsibility (1979) is directed in part to the problem of private use of confidential government information. E.g., Armstrong v. McAlpin, 606 F.2d 28, 32-33 (2d Cir. 1979), rev'd on other grounds, 625 F.2d 433 (2d Cir. 1980) (en banc) (DR 9-101(B) enforces policies against unfair use and disclosure of confidential information); Board of Educ. v. Nyquist, 590 F.2d 1241, 1247 n.I (2d Cir. 1979) (Mansfield, J., concurring) (concern about private use of confidential government information implicit in DR 9-101(B)).

6. 18 U.S.C. $\$ 207$ (Supp. III 1979).

7. A recent article has discussed the fiduciary duty of present government employees. See Kalo, supra note 5. It does not, however, provide guidelines as to what government 
several advantages over the exclusive use of Title V's "bright-line" rules and its criminal and administrative sanctions. Most importantly, legal actions to enforce a fiduciary duty could reach all instances of use of confidential or inaccessible information by former officials. In addition, suit could be brought either by the government or by certain private parties, and could seek relief through an injunction, through recovery of a delinquent fiduciary's profits, or through damages if appropriate. Because enforcement of a general fiduciary duty would be more comprehensive and more effective than Title V's system of rules and sanctions, it would better serve the public interest in governmental efficiency, fairness, and integrity.

\section{Policies in the Regulation of Post-Government Employment}

When a government servant $t^{8}$ leaves his post to enter the private sector, he may well take with him confidential information about the government ${ }^{9}$ or, particularly if he enters a field with which he dealt while in government, about his private employer's competitors. ${ }^{10}$ If the departing public employee uses that information to benefit himself or his new employer, his activities may violate such basic values as equal treatment by the government ${ }^{11}$ and equal opportunity to

information is "confidential" and therefore protected by the duty, nor does it assess the problem of private use of government information by former public employees, as this Note docs. Furthermore, since publication of the article, passage of the Ethics in Govcrnment Act of 1978 has altered regulations affecting former government servants, which the fiduciary doctrine must take into account. Kalo also proposes a citizens' right of action based on class actions that is different from the government and private causes of action that this Note recommends. See note 87 infra (discussing differences).

8. Although this Note concentrates on former federal employees, the fiduciary doctrine that it recommends applies as well to state and local government servants. Those cmployees may also misuse confidential information, see N.Y. Times, Jan. 27, 1980, \& 1, at 26, col. 3 (former city budget specialist accused of using inside knowledge of city finances to help municipal labor union win bigger wage settlement), and states have begun to recognize that the concept of a fiduciary duty provides a remedy, see note 61 infra (citing cases). In some instances, different bodies of state common law may lead to different results. See note 117 infra (differences in punitive damages).

9. See, e.g., Alfred A. Knopf, Inc. v. Colby, 509 F.2d 1362 (4th Cir.), cert. denied, 421 U.S. 992 (1975) (classified CIA information); Empire Linotype School, Inc. v. United States, 143 F. Supp. 627 (S.D.N.Y. 1956) (information about government contracts); N.Y. Times, Feb. 19, 1980, $\$ A$, at 1 , col. 3 (information about FBI Abscam investigation).

10. Cf. Exchange Nat'l Bank of Chicago v. Abramson, 295 F. Supp. 87, 92 (D. Minn. 1969) (plaintiff alleged but failed to show that intervening party had obtained confidential information while serving as government witness in related litigation two years before).

11. A government employee who dispenses special favors breaches a fundamental duty to serve the public. See, e.g., United States v. King, 469 F. Supp. 167, 170-71 (D.S.C. 1979) (Foreign Service officer breached duty by giving favorable treatment to visa applications in return for special payment); United States v. Podell, 436 F. Supp. 1039, 1042 (S.D.N.Y. 1977) (Congressman who lobbied for private airline for pay violated duty of disinterested advocacy owed to government and constituents); H.R. Con. Res. 175, 72 
compete. ${ }^{12}$ He or his employer may use the information to obtain special treatment from the government, to exploit or evade a government program, ${ }^{13}$ or to gain advantages over private competitors. In addition, such unfair uses of information will have secondary effects, discouraging the full disclosure that is necessary to the administration of government programs ${ }^{14}$ and raising public doubts about integrity in government. ${ }^{15}$ These secondary effects will in turn interfere with the workings of government. ${ }^{16}$

Stat. B12 (1958) (Code of Ethics for Government Service: “5. [Government employees shall $n$ ]ever discriminate unfairly by the dispensing of special favors or privileges to anyone....")

12. See Tool Co. v. Norris, 69 U.S. (2 Wall.) 45, 54 (1865) (invalidating contract to obtain supply contract from War Office because such contracts "directly lead to inefficiency in the public service, and to unnecessary expenditures of the public funds"). The user of confidential government information has an advantage over his competitors, and the result is economically inefficient because the advantage is unrelated to the user's product or services. An inferior producer may surpass a superior competitor simply by timely acquisition of confidential government information.

Arguably, in some cases, private use of confidential government information may be the best use of that information. Selective disclosures of such information by former government employees, however, will not necessarily produce those results because former employees have no personal interest in keeping information secret and cannot calculate the value of the government's interest in confidentiality. Thus information may be sold too cheaply. Furthermore, disclosures of government information to achieve efficient results should be made systematically. Decisions as to what information to release and when to release it cannot be left up to to individuals.

13. See United States v. Mississippi Valley Generating Co., 364 U.S. 520, 551-54, 556-59 (1961) (consultant to government on cost of money supplied information to power company and bank to help them negotiate contract with United States); United States v. Drisko, 303 F. Supp. 858, 860 (E.D. Va. 1969) (employee gave information to government program participant as part of plan to obtain favorable treatment of participant's claims against government).

14. Cf. FTC v. Texaco, Inc., 517 F.2d 137, 148 \& n.25 (D.C. Cir. 1975), cert. denied, 431 U.S. 974 (1977) (appellees resisted compliance with subpoenas duces tecum because of fear that competitors could obtain information sought); United States v. Illinois Fair Plan Ass'n, 67 F.R.D. 659, 661-62 (N.D. Ill. 1975) (acknowledging purpose of government confidentiality to encourage candor from regulated businesses, but ordering discovery because that policy not obstructed); Reauthorization of the Commodity Futures Trading Commission: Hearings Before the Subcomm. on Agricultural Research and General Legislation of the Senate Comm. on Agriculture, Nutrition, and Forestry, 95th Cong., 2d Sess., pt. II, 556-57 (1978) (statement of Bennett J. Corn) (urging that CFTC be required to keep information confidential so that traders will not hesitate to send commodities exchanges necessary information).

15. Restoring public confidence in the government is one goal of Title V. See Regulations Concerning Post Employment Conflict of Interest, 5 C.F.R. $\$$ 737.1(c)(1) (1980); S. REP. No. 95-170, 95 th Cong., lst Sess. 32-34, reprinted in [1978] U.S. Code Cong. \& AD. News 4216, 4248-50 [hereinafter cited as SEnAte REPORT with page citations to U.S. Code Cong. \& Ap. News].

16. See United States v. Mississippi Valley Generating Co., 364 U.S. 520, 562 (1961) (" $[A]$ democracy is effective only if the people have faith in those who govern, and that faith is bound to be shattered when high officials and their appointees engage in activities which arouse suspicions of malfeasance and corruption."); SPEcial CommitTeE on the federal Conflict of Interest laws, Association of the Bar of the City of New YoRK, supra note 5, at 6-7 (preservation of public confidence is "intensely pragmatic concern"). 
Certain restrictions should be placed, then, on the post-employment activities of former government employees. These restrictions should promote policies of equal access to government information, equal treatment by the government, efficient administration of government programs, and protection against private gain on the basis of confidential government information. Ideally, integrity in government would flow from such equal treatment..17

Any restrictions must take account, however, of the policies militating against limits on the use of information obtained while in the public employ. ${ }^{18}$ Limitations on post-government career opportunities may discourage talented people from entering government service, where salaries are lower than in private industry. ${ }^{19}$ Furthermore, restrictions may prevent the use of personal knowledge and skills that a public employee acquired on his own, not as a unique result of government service. ${ }^{20}$

The desired calculus of these policies-protecting values of equality and efficiency without placing undue restraints on personal talents and decisions-narrows the range of possible limitations on postgovernment employment. Such limitations must be comprehensive

17. Equal access to information should reduce the perceived need to use influence. Cf. SENATE REPORT, supra note 15 , at 4247 (elimination of undue influence and unequal access to information will produce honest government).

18. The scope of a former public servant's First Amendment right to speak about the government is unclear. Whether a disclosure is protected will depend on particular characteristics of the information revealed that are outside the range of this Note's discussion. The fiduciary duty proposed in this Note does not rely on an explicit contract, so First Amendment questions are not so easily passed over as they were in Snepp v. United States, 444 U.S. 507, $509 \mathrm{n} .3$ (1980). Indeed, under the standard recommended in this Note, see pp. 202-04 infra, no duty would have existed in Snepp because the information involved was not confidential. $C f$. Snepp v. United States, 444 U.S. 507, 518-21 (1980) (Stevens, J., dissenting) (Snepp had duty only with respect to truly confidential information). Furthermore, the government's recovery would have been restricted to that portion of the profits that it showed had arisen out of the use of confidential information. See pp. 204.05 infra. For a discussion of the appropriateness of a fiduciary duty arising by contract, with which the Snepp decision independently agreed, see Comment, 32 StAN. L. Rev. 409, 424-25 (1980).

19. The complaint is common that restrictions on post-government employment will have this effect. See, e.g., Hearing on H.R. 6954 Before the Investigations Subcomm. of the House Comm. on Armed Services, 95th Cong., Ist Sess. 24-27 (1977) (statement of Dr. Harold Rosenbaum); id. at 11 (comments of Congressman Stratton); Conduct of Government Personnel: Hearings on S. 695 Before the Senate Comm. on Banking, Housing, and Urban Affairs, 95th Cong., Ist Sess. 45 (1977) (statement of Alan K. Campbell, Chairman, U.S. Civil Service Commission); id. at 100-01 (comments of Senator Schmitt). But see id. at 52 (comments of Senator Proxmire) (questioning whether such deterrent effect exists).

20. One of the attractions of government service is the training it provides. See, e.g., Disclosure Act Hearings, supra note 5, at 568 (statement of Congressman Bob Eckhardt) (commenting on value of experience at SEC); Conduct of Government Personnel: Hearings on S. 695 Before the Senate Comm. on Banking, Housing, and Urban Affairs, supra note 19, at 94 (statement of David Cohen, President, Common Cause) (recognizing that government service provides valuable training and experience). 
enough to deal with the wrong they purport to address, but specific enough not to discourage all public service. The present restrictions in Title $\mathrm{V}$ of the Ethics in Government Act of 1978 fall outside that range.

\section{The Ethics in Government Act}

Until recently, federal law reflected only piecemeal attempts to deal with the exploitation by former government employees of information obtained during their tenure. ${ }^{21}$ The Ethics in Government Act of 1978 (Act), ${ }^{22}$ however, introduced important and wide-ranging postemployment restrictions on government officials. Title $V$ of the Act presents a series of "bright-line" rules for former federal employees that disqualify them, temporarily or permanently, from communicating with or appearing before their former departments or agencies with respect to certain matters. ${ }^{23}$ Although the Act provides both criminal $^{24}$ and administrative penalties, implementation of the law depends primarily on administrative sanctions, ${ }^{25}$ such as a prohibition

21. A few statutes contain restrictions, ranging from prohibitions of activities to reporting requirements, directed to specific employees. Only one statute appears to bar any post-employment activity. See 15 U.S.C. $\$ 2053(\mathrm{~s})(2)(1976)$ (senior Consumer Product Safety Commission employees may not work for manufacturers subject to Consumer Product Safety Act in first year after leaving CPSC). Similar temporary bars apply to directors of some agencies who do not serve full terms. See, e.g., 12 U.S.C. $\$ 242$ (Supp. III 1979) (Governor of Federal Reserve Board may not work for any member bank for first two years out); 47 U.S.C. $\S$ I54(b) (1976) (Federal Communications Commissioner may not represent anyone before FCC in first year out). Reporting requirements, which might be seen as indirect restraints, apply to certain employees involved with government contracts. See 42 U.S.C. $\$ 2462(b)(1)$ (1976) (former National Aeronautics and Space Administration employees must file reports regarding their work for NASA contractors); 50 U.S.C. $\$ 1436(b)(1)$ (1976) (same requirement for former senior Defense Department employces working for Defense Department contractors). The statute making criminal any conspiracy to defraud the United States, 18 U.S.C. $\$ 371$ (1976), has also been used to punish users of confidential government information. E.g., Haas v. Henkel, 216 U.S. 462 (1910); United States v. Peltz, 433 F.2d 48 (2d Cir. 1970), cert. denied, 401 U.S. 955 (1971). The openended quality of the crime as defined in the statute, however, suggests that the statute be applied sparingly. See generally Goldstein, Conspiracy to Defraud the United States, 68 YALE L.J. 405 (1959).

Other methods used to control former employees include CIA secrecy agreements, sec, e.g., Snepp v. United States, 444 U.S. 507 (1980) (enforcing agreement), and DR 9-101(B) of the ABA Code of Professional Responsibility, see, e.g., United States v. Ostrer, 597 F.2d 337, 340 n.6 (2d Cir. 1979) (disqualifying defendanc's counsel because he had gained information related to case while working as government prosecutor).

22. 18 U.S.C. $§ 207$ (Supp. III 1979).

23. Id. $\S 207(\mathrm{a})$-(c). The length and nature of the restrictions depend on the former employee's prior involvement in the matter, the nature of the matter he now seeks to represent, and his prior employment grade.

24. Maximum penalties are a $\$ 10,000$ fine or two years imprisonment or both. 18 U.S.C. $\$ 207$ (c) (Supp. III 1979).

25. 5 C.F.R. $\$ 737.1(c)(6)$ (1980); see SENATE REPoRT, supra note 15, at 4250 (reluctance to enforce criminal penalties requires administrative sanctions). 


\section{Ex-Government Employees}

of appearances before or communications to the department or agency involved for a period of up to five years. ${ }^{26}$ Agencies and departments have primary responsibility for enforcing the post-employment rules ${ }^{27}$ and are to advise former employees who have specific problems. ${ }^{28}$

Although these restrictions improve previous law, their overall effectiveness is limited by the narrow scope of Title V's rules and by the defects in its system of sanctions. These shortcomings undermine both the Act's attempt to address the problem of undue influence, which is its principal concern, ${ }^{29}$ and its effort to confront the more fundamental problem of the abuse of government information.

\section{A. Limitations on Scope}

Title V's scope is restricted in several respects: to appearances before or communications with departments or agencies, to particular matters involving specific parties, to matters in which the former employee participated substantially or over which he had official responsibility, and, in some cases, to matters occurring within a certain time period. These limitations reduce the range of abuses that the law is able to reach.

First, some of the Act's provisions, because they apply only to an appearance before or a communication with a department or agency, ${ }^{30}$ do not reach many private uses of confidential information. Knowledge of a contemplated enforcement policy for a government program, for example, could assist an employer in concealing activities from government scrutiny. Even where an appearance or communication will take place, work by a former government employee preparatory to the event is clearly permissible, ${ }^{31}$ even if such work circumvents the law's attempt to eliminate undue personal influence. In addition, the unfair competitive advantage that a private employer might gain from information held by a former public servant is unrelated to contact with the government.

Second, provisions limiting Title V's scope to certain "particular

26. 18 U.S.C. $\$ 207(\mathrm{j})$ (Supp. III 1979); see 5 C.F.R. $\$ 737.27(\mathrm{a})(9)(\mathrm{i})(1980)$.

27. 5 C.F.R. $\$ 737.1(c)(6)(1980)$.

28. Id. $\$ 737.1(\mathrm{c})(8)$. An Office of Government Ethics in the Office of Personnel Management of the Civil Service Commission is available to advise agencies on questions they may have. Id.

29. See Senate RePort, supra note 15 , at $4247-50$. The report also indicates that the law was intended to reach unfair uses of information as well. See id.

30. 18 U.S.C. $\$ 207($ a), (b)(i), (c) (Supp. III 1979) ("any formal or informal appearance ... [or] any oral or written communication").

31. 5 C.F.R. $\$ 737.5$ (b)(5) (example 1) (1980). 
matters' 32 further narrow the law's coverage. Participation in broader government matters-the making of policy, the formulation of regulations-will not subject the participant to any of the Title $V$ restrictions when he leaves office. ${ }^{33}$ Yet experience in these matters may provide as much confidential information as involvement in more specific concerns. ${ }^{34}$

Third, portions of Title $\mathrm{V}$ require that a former employee have "participated personally and substantially" 35 in a matter or had it "under his official responsibility" 38 before his post-employment activity with respect to that matter is limited. ${ }^{37}$ An employee may learn of confidential information, however, in connection with something with which he was only marginally involved. ${ }^{38}$ The extent of the private use of that information and of the inefficiencies it will create are largely unrelated to how much work the former servant did with the information while in government.

Finally, the temporary quality of many of the Act's restrictions reduce their potential effectiveness even as to the limited class of abuses they address. The rules contained in subsections (b) and (c) of section $207^{39}$ assume that information will become less confidential

32. See, e.g., 18 U.S.C. $\$ 207(a)(2)$, (b)(2) (Supp. III 1979) ("any judicial or other proceeding, application, request for a ruling or other determination, contract, claim, controversy, investigation, charge, accusation, arrest, or other particular matter involving a specific party or parties"). "Rulemaking" is another matter forbidden to former highlevel officials. Id. $\S 207$ (c). "Rulemaking" includes the adoption of regulations and the implementation of projects but not broad technical or policy issues discussed before a program has become a project. 5 C.F.R. $\$ 737.11(\mathrm{c})(1980)$.

33. 5 C.F.R. $\$ \S 737.5$ (c)(1), 737.7(d) (example 1), 737.11(c) (1980).

34. Cf. United States v. Standard Oil Co., 136 F. Supp. 345, 350.59 (S.D.N.Y. 1955) (defense to conflict of interest charge on ground that employment at government branch office did not give improper access to information that might have been available at central, policy-making office).

35. 18 U.S.C. $\$ 207$ (a) (Supp. III 1979) ("participated personally and substantially as an officer or employee through decision, approval, disapproval, recommendation, the rendering of advice, investigation or otherwise").

36. Id. $\S 207(\mathrm{~b})(3)$ (no contact concerning a matter "which was actually pending under his official responsibility as an officer or employee").

37. Former high-level officials are barred temporarily from all contacts with their department or agency respecting a matter pending before it or in which it has "a direct and substantial interest." $I d$. $\$ 207(c)(3)$. The official's prior participation in the matter is irrelevant. 5 C.F.R. $\$ 737.11(\mathrm{~b})$ (1980).

38. See 5 C.F.R. $\$ \S 737.5(\mathrm{~d})(\mathrm{I})-(2), 737.7(\mathrm{~b})(3)$ (example 1) (1980) (responsibility for ancillary aspects of a matter does not subject former employee to restrictions for substantial participation or official responsibility); cf. United States v. Drisko, 303 F. Supp. 858, 860 (E.D. Va. 1969) (employee in one division of Agriculture Department supplied confidential information from another division).

39. 18 U.S.C. $\$ 207$ (b), (c) (Supp. III 1979). Although subsection (a) of section 207 imposes a permanent bar on certain activities of former government employees, the restrictions in subsections (b) and (c) last only for one or two years. Moreover, these periods begin to run as soon as the employee has left his area of responsibility, whether or not he leaves the government at that time. 
or less useful in one or two years; not all information, however, will deteriorate so rapidly. ${ }^{40}$ The additional time restriction in section 207(b)(3), ${ }^{41}$ specifying that a regulated situation must involve a matter that appeared before the former employee in his last year of service, similarly reduces the Act's protection.

As a result of these four limitations on Title V's scope, the law is both under-inclusive and over-inclusive. Its restrictions fail to prohibit the use of confidential information when characteristics of contact, particular matter, prior participation, and, in some instances, time, are not present. Yet the same restrictions may bar activities that exhibit those characteristics but that include no undue influence or use of confidential information. One consequence of these limited and inconsistent rules is the knowledge that one will be restricted in his career after leaving government, despite the absence of any wrongdoing. This factor may account, in part, for Title V's perceived disincentive to government service. ${ }^{42}$

\section{B. The System of Sanctions}

The effectiveness of Title V's system of sanctions is reduced by two defects. First, the existing penalties cannot be tailored to fit the intended wrongs. The administrative penalties, Title V's principal enforcement mechanisms, are insensitive to the seriousness of the violation. A wrongdoer, for example, may be barred from appearing before an agency or department for a certain length of time, ${ }^{43}$ but the impact of the penalty will depend largely on how often the wrongdoer would otherwise have made such appearances and on how much he would have earned, factors wholly unrelated to the extent

40. Although the paradigmatic problem will arise when a government official gains possession of confidential information and, realizing its current value, leaves government service in order to exploit it privately, some information will remain valuable over a long period of time, in which case an official might not decide to use it until several years after leaving government. For example, early results from scientific tests conducted over several years will have value until the results are released. Regulations governing the availability of department and agency information in the National Archives assume that some information has long-term value and should not be made public for several years. See 41 C.F.R. $\$ 105-61.53$ (1979). Litigation will also prolong the value of information. See, e.g., Empire Linotype School, Inc. v. United States, 143 F. Supp. 627, 629.32 (S.D.N.Y. 1956) (information acquired two-and-a-half to six years before still confidential).

41. 18 U.S.C. $\$ 207(b)(3)$ (Supp. III 1979) ("within a period of one year prior to the termination of such responsibility").

42. See Wall St. J., Jan. 4, 1980, at 1, col. 5 (Ethics in Government Act has caused more people to leave government service and has made recruiting for SEC more difficult); cf. Tolchin, New Law Hasn't Set Off Mass Loss of U.S. Aides, N.Y. Times, June 4, 1979, $\S \mathrm{B}$, at 10 , col. 5 (no flood of departure from government in response to Title V's rules, but recruiting expected to be more difficult).

43. The prohibition may last up to five years. 18 U.S.C. $\$ 207(j)$ (Supp. III 1979). 
of the wrong the government seeks to punish. Furthermore, commission of a wrong under Title $V$ might be so profitable that a wrongdoer would accept any administrative sanction, knowing that the government would be reluctant to bring a criminal suit, ${ }^{44}$ given the relative severity of the criminal penalties. ${ }^{45}$ Indeed, the framers of Title $\mathrm{V}$ recognized that criminal proceedings would be brought infrequently. ${ }^{46}$ Thus the sanctioning system is not responsive to the severity of a violation: it provides unadjustable administrative penalties, and supplies no intermediate enforcement option between those penalties and harsh criminal sanctions. ${ }^{47}$

Second, Title V's administrative mechanisms may produce underenforcement. The lack of standards to guide imposition of administrative sanctions may lead to inconsistent penalties. ${ }^{48}$ Furthermore, the Act relies for implementation on the vigilance of the agency or department involved. ${ }^{49}$ This implementation strategy risks defeat by the very means that the Act seeks to block: the exercise of undue influence. An ex-government employee's contacts with his former agency are prohibited so that he may not unfairly influence former colleagues; yet Title $\mathrm{V}$ makes those colleagues, who presumably are

44. See SENATE REPORT, supra note 14 , at 4250 (observing "great reluctance to bring a criminal indictment against a former high level official" under the previous statute, whose penalties were lighter); Disclosure Act Hearings, supra note 5, at 560-63 (testimony of Thomas Henderson, Jr., Chief, Public Integrity Section, Criminal Division, Department of Justice) (discussing reluctance of Public Integrity Section to proceed criminally for ethics violations). Even if the government were to use criminal penalties more regularly, juries might still avoid convicting individual white collar defendants. See Note, Structural Crime and Institutional Rehabilitation: A New Approach to Corporate Sentencing, 89 YALE L.J. 353, $359 \mathrm{n.35}$ (1979) (discussing cases in which juries convict corporations while acquitting co-defendant officers); Note, Decisionmaking Models and the Control of Corporate Crime, 85 YALE L.J. 1091, 1096 n.27 (1976) (same).

45. 18 U.S.C. $\$ 207$ (c) (Supp. III 1979) (providing for penalties of up to $\$ 10,000$ or two years' imprisonment or both).

46. See 5 C.F.R. $\$ 737.1(c)(6)$ (1980) (giving agencies primary responsibility for enforcement of restrictions and recommending that criminal suits be brought only "in cases involving aggravated circumstances"); SENATE REPORT, supra note 15, at 4250 (noting reluctance to bring criminal suits and therefore providing administrative sanctions in Title V); cf. United States v. Conlon, 26 Crim. L. REP. (BNA) 2201, 2203 (D.D.C. Oct. 26, 1979) (noting "longstanding Congressional view that criminal penalties should be applied with care to the difficult area of conflicts of interest").

47. A similar problem of light penaities failing to deter wrongdoing and of other possible penalties being deemed too severe to apply to that wrongdoing arises in federal income tax enforcement. See Asimow, Civil Penalties for Inaccurate and Delinquent Tax Returns, 23 U.C.L.A. L. REv. 637, 638-52 (1976) (discussing inadequacy of IRS fraud and negligence penalties and recommending intermediate sanctions).

48. See Thomforde, Patterns of Disparity in SEC Administrative Sanctioning Practice, 42 TENN. L. REv. 465, 497-524 (1975) (finding that under "public interest" standard for sanctioning, SEC penalizes broker-dealers not affiliated with New York Stock Exchange more severely than affiliates without articulating basis for disparity).

49. 5 C.F.R. $\$ 737.1(c)(6)$ (1980) (agencies have primary responsibility for enforcement). 
susceptible to influence, responsible for reporting the ex-employee's violation.

\section{Toward a Fiduciary Duty for Former Government Employees}

The defects of Title $V$ require a supplementary program to ensure that persons who occupy positions of public trust do not misuse confidential government information once they leave public service. The doctrine of a fiduciary duty, extended to hold former employees under a duty to the government, will meet the problems of post-government employment unsolved by Title $\mathrm{V}$.

\section{A. Foundation of the Duty}

A fiduciary duty arises out of a relationship of trust.50 A fiduciary is relied on to protect the interests of a principal, which often means putting assets, including confidential information, ${ }^{51}$ to the use of that principal. The duty requires that a fiduciary not act in his own interest at the expense of his principal' ${ }^{52}$ and not use personally any assets coming to him in the course of the relationship without permission from the principal.53 Taking advantage of such a relationship amounts to unjust enrichment, ${ }^{54}$ with remedies lying in equity. ${ }^{55}$ In

50. I A. Scott, The Law of Trusts 39 (3d ed. 1967). The term "trust" is used in a non-technical sense, simply connoting faith in and reliance on someone. See Tate v. Williamson, L.R. 2 Ch. 55, 61 (1866) (fiduciary relationship exists where confidence is reposed by one in another and influence is possessed by another); Sealy, Fiduciary Relationships, 1962 CAMIBRIDGE L.J. 69, 70-71 (fiduciary relationship originally identified as "trust" in its general sense).

51. See, e.g., Tlapek v. Chevron Oil Co., 407 F.2d 1129 (8th Cir. 1969) (theory of location of oil and gas deposits).

52. See, e.g., Higgins v. Shenango Pottery Co., 279 F.2d 46, 48-54 (3d Cir.), cert. denied, 364 U.S. 899 (1960) (corporate officers accountable for profits on contract diverted from corporation to own partnership); Ragnar Benson, Inc. v. Kassab, 325 F.2d 591, 592-94 (3d Cir. I963) (accounting ordered for similar diversion by corporate officer to own corporation). This duty has been construed severely from its inception. See Keech v. Sanford, 25 Eng. Rep. 223 (Ch. 1726) (trustee of lease accountable for renewing lease in own interest rather than for beneficiary, even though lessor had refused to renew lease to trustee as trustee for beneficiary).

53. See, e.g., Moran v. Edson, 493 F.2d 400, 406-07 (3d Cir. 1974) (corporate assets used to pay directors' life insurance premiums and excessive rent); Hunter v. Shell Oil Co., 198 F.2d 485 (5th Cir. 1952) (confidential information about oil and gas deposits); Components for Research, Inc. v. Isolation Prods., Inc., 241 Cal. App. 2d 726, 728-29, 50 Cal. Rptr. 829, 830-32 (1966) (secret manufacturing process).

54. See 5 A. Scorr, supra note 50, at $3410-13$, 3417-18 (breach of fiduciary duty one form of unjust enrichment that constructive trust will remedy). Breach of fiduciary duty is also considered a type of fraud, see, e.g., United States v. Carter, 217 U.S. 286, 305-06 (1910), although this analogy has been criticized, see Tlapek v. Chevron Oil Co., 407 F.2d 1129, 1133-34 (8th Cir. 1969).

55. See H. McClintock, Handbook of The Principles of Equity 406-07 (2d ed. 1948) (equity protects trade secrets and other confidential information); id. at 538-39 (fiduciary's cquitable duty to account). The remedy often used is imposition of a constructive trust 
addition, a third party who receives any fruits of the breach of duty ${ }^{56}$ or who purchases them with notice of the breach ${ }^{57}$ is also accountable for them.

Because "[a p]ublic office is a public trust," 58 a fiduciary duty and corresponding remedies should be recognized to exist for former government employees. The model for the duty is private sector employment, in which an employer may sue for a breach of duty that occurs while an employee is in his hire. ${ }^{59}$ But the fiduciary doctrine extends beyond this model in ways that reinforce its applicability to the former public servant. First, the duty extends to a former employee concerning certain information acquired during his term of employment. An employer may rely on an employee to keep certain information confidential, and only when that reliance ends does the corresponding duty end, regardless of when employment was terminated. ${ }^{00}$ Second, a fiduciary duty is already recognized to extend to employees of the federal government, insofar as the government entrusts to its employees confidential job-related information. ${ }^{61}$ The government,

on the fiduciary's profits for the benefit of the principal. See Restatement of REstituTION $\S 200$ (1936) (fiduciary holds property acquired through use of principal's confidential information as constructive trustee). A classic formulation is Judge Cardozo's: "[a] constructive trust is then the remedial device through which preference of self is made subordinate to loyalty to others." Meinhard v. Salmon, 249 N.Y. 458, 467, 164 N.E. 545,548 (1928).

56. Anyone who receives property without paying for it, if that property was wrongfully acquired from someone else, is enriched unjustly, whether or not he knows about the wrong. $4 \mathrm{~A}$. Scotr, supra note 50, at 2343-44.

57. See Servo Corp. v. General Elec. Co., 337 F.2d 716, 722-25 (4th Cir. 1964), cert. denied, 383 U.S. 934 (1966) (where plaintiff conveyed trade secret confidentially to customer, defendant competitor liable for appropriating secret through contacts with customer). Notice may consist of either actual notice of the breach of duty or "constructive" notice; the latter occurs when the third party knows facts that under the circumstances would lead a reasonably intelligent and diligent person to inquire whether a breach of duty will be committed by completing the transfer. 4 A. ScoTr, supra note 50, at 2404-06; 5 id. at 3457-58; see Restatement of Agency $\$ 9$, Comment d (1933) (defining "should know"), incorporated by reference in RestateMENT OF REstitution $\$ 174$, Comment $a$ (1936) (defining notice). At least where he has an opportunity to do so, the principal must notify the third party of the alleged breach. See Ragnar Benson, Inc. v. Kassab, 325 F.2d 591, 595-96 (3d Cir. 1963) (principal visited third party but failed to mention breach).

58. City of Boston v. Dolan, 298 Mass. 346, 354, 10 N.E.2d 275, 281 (1937).

59. See Sealy, supra note 50, at 74-77, 79-80 (master-servant a common relationship that gives rise to fiduciary duties); cf. Weinrib, The Fiduciary Obligation, 25 U. Tononto L.J. 1 (1975) (fiduciary obligation based on policies of controlling agent's discretion and protecting commercial organization).

60. See, e.g., Raines v. Toney, 228 Ark. 1170, 1180-81, 313 S.W.2d 802, 809-10 (1958) (even if evidence supported corporate officer's claim that he had resigned, fiduciary duty continued after that time); Opie Brush Co. v. Bland, 409 S.W.2d 752, 757-59 (Mo. App. 1966) (corporate officer liable for use of principal's confidential information in competing business even though he had resigned).

61. See, e.g., United States v. Mississippi Valley Generating Co., 364 U.S. 520, 551, 556-59 (196I) (government construction contract rescinded where government agent, as 
moreover, has an even greater interest in the loyalty of its employees than does a private employer. ${ }^{62}$ As with private employees, the termination of employment does not end the duty: a former employee possesses information that the government still expects him to keep confidential. ${ }^{63}$ The fiduciary doctrine, then, should be recognized to apply to former public employees. ${ }^{64}$

This duty to the government ought not obscure the government's general obligation to be accessible. ${ }^{65}$ The government should readily

part of violation of federal conflict of interest statute, supplied government information to contractor); United States v. Drisko, 303 F. Supp. 858, 860 (E.D. Va. 1969) (employee of Agriculture Department accountable for profits received for giving confidential Department information to private party). Similar duties are owed to state governments by state officials. See, e.g., City of Boston v. Dolan, 298 Mass. 346, 10 N.E.2d 275 (1937) (mismanagement of city securities); City of Minneapolis v. Canterbury, 122 Minn. 301, 307-09, 142 N.W. 812, 814-15 (1913) (sale by city procurement agent of own property to city); Driscoll v. Burlington-Bristol Bridge Co., 8 N.J. 433, 474-77, 86 A.2d 201, 221-23 (1952) (improper sale of bridge).

62. In addition to the government's interest in keeping certain information confidential so that it may run its programs more effectively, two other interests strengthen the duty owed to the government. First, greater dislocations may occur through use of government information because a private business may gain an advantage against government regulators as well as against its competitors, while private information will bring only a private competitive advantage. Second, such a duty enhances loyalty and honesty in government, often conceived of as good in itself, see, e.g., United States v. Kearns, 595 F.2d 729, 733-34 (D.C. Cir. 1978), and also increases confidence in the government, a factor in the effective operation of government programs, see p. 192 supra.

63. Provisions in the Code of Professional Responsibility covering lawyers' post-employment duty include this principle, although the Code's rule applies at the point of access to confidential information rather than at the point of use of information. $C f$. note 4 supra (citing cases from which former government lawyers barred because of previous access to government information).

64. There appear to be no cases in which the federal government has sued to recover the profits that an ex-official made in breach of his post-employment duty, absent an express post-employment agreement, such as the CIA requires. Justice Stevens, however, has suggested that the government could sue under such circumstances. Snepp v. United States, 444 U.S. 507, 518 (1980) (Stevens, J., dissenting); cf. Comment, 32 StaN. L. Rev. $409,422-26$ (1980) (applying fiduciary concept to Snepp). The government also has obtained injunctions against former employees' uses of confidential information. In United States v. Mahaney, 27 F. Supp. 463 (N.D. Cal. 1939), the SEC sued to enjoin one of its former attorneys and the defendant corporations from using confidential information that the attorney had obtained while with the SEC. In granting the injunctions, the District Court relied primarily on the attorney's violation of the Canons of Professional Ethics in representing a private party in a matter with which he was involved while at the SEC. Id. at 466-68. The defendant corporations were also temporarily enjoined from using the information because "the facts clearly warrant[ed]" it. Id. at 468-69. The only explanation for the court's action seems to be that a third party purchaser of information supplied in breach of a confidential relationship-a fiduciary duty-cannot be permitted to keep it. For further discussion of third party accountability, see notes 57 supra, 84-85 \& 113 infra; cf. Alfred A. Knopf, Inc. v. Colby, 509 F.2d 1362 (4th Cir.), cert. denied, 421 U.S. 992 (1975) (enjoining publication of classified CIA information, relying on former CIA agent's secrecy agreement and national security grounds).

65. See, e.g., H.R. REP. No. 1497, 89th Cong., 2d Sess. 30 reprinted in [1966] U.S. CODE CONG. \&: AD. NEWS 2418, 2429 (new government information act responds to obliga- 
give permission to use information that it possesses. ${ }^{66}$ In this way, information that should be used can be used, thus enhancing efficiency interests without forcing private businesses to run the risk of litigation. Private employers, in turn, would have an incentive not to assist breaches of fiduciary duty and would instead seek permission. Implementation of this exception to the fiduciary rule would require that departments and agencies establish their own procedures for granting permission, procedures that presumably would ensure equal access to the government by permission seekers and promote fair and reasonably consistent responses. ${ }^{67}$

\section{B. Content of the Duty}

The meaning of "confidential government information" will determine the scope of the fiduciary doctrine. In all cases, the definition should guarantee that enforcement of the fiduciary duty will promote the basic policy on which it rests: equal opportunity to use information. Although the question whether equal opportunity exists can be determined only in individual factual settings, certain guidelines may be suggested. Clearly, information made public by the government would not be protected by the fiduciary duty, whereas classified information would be. ${ }^{68}$ The securities law concept of inside information, ${ }^{69}$ which was designed with a similar intent to guarantee equal access to information, ${ }^{70}$ suggests a test for determining when infor-

tion of open government). For a discussion of the obligation and how the government should fulfill it, see Note, The First Amendment Right to Gather State-Held Information, 89 YALE L.J. 923 (1980).

66. A fiduciary in any context may use confidential information if the principal permits him to do so. See 5 A. Scort, supra note 50, at $3469-70$. Permission must be clear, however. See United States v. Mahaney, 27 F. Supp. 463, $468-69$ (N.D. Cal. 1939) (finding no evidence to support claim that SEC consented to have former SEC attorney represent adverse party); cf. Tlapek v. Chevron Oil Co., 407 F.2d 1129, 1133-34 (8th Cir. 1969) (holding that openness of defendant's wrongful conduct was no defense because mere secrecy is not touchstone for breach of fiduciary duty).

67. Departments and agencies should be equipped to predict the effect that the private use of information will have on their programs and to measure that effect against the benefits of the proposed use. The government's ability to grant permission should be constrained by two factors, however. First, because private sources of confidential information may still have an interest in confidentiality, the government should deny permission to use that information unless the source also consents. Second, permissions must stay within the bounds of statutes limiting disclosure of government information.

68. See Alfred A. Knopf, Inc. v. Colby, 509 F.2d 1362 (4th Cir.), cert. denied, 421 U.S. 992 (1975) (enjoining publication of classified CIA information).

69. This Note does not recommend a "material inside information" test. The flexibility of the constructive trust remedy, see note 55 supra, which imposes liability in proportion to the profits attributable to the misuse of information, makes a materiality standard unnecessary.

70. See SEC v. Texas Gulf Sulphur Co., 401 F.2d 833, 848, 851-52, 858 (2d Cir. 1968) (en banc), cert. denied, 394 U.S. 976 (1969) (Rule 10b-5 based on policy of giving all 
mation becomes public. Publication occurs when "such information ... [has] been effectively disclosed in a manner sufficient to insure its availability to the investing public." 71 The similar policy of equal access underlying the fiduciary concept thus should allow a former government employee to act on information only after it is published in the Federal Register or in another generally available official publication, or has been disseminated widely by the news media.

Implementation of this general rule will require certain refinements in order to meet the goal of equal access to information, as well as to clarify the content of the duty and to avoid imposing unfair disabilities on former government employees and their private employers. The showings plaintiff is required to make in a suit for breach of fiduciary duty ${ }^{72}$-that the information used was confidential, that profits were gained by its use, and, to recover from a third party, that the party had notice of the breach-provide a framework for discussing modifications of the duty.

To demonstrate the confidentiality of information, plaintiff should show that the information was available only to government employees. ${ }^{73}$ If some outsiders also had access, ${ }^{74}$ then it could not be asserted that a public employee had taken advantage of privileged information. ${ }^{75}$ In addition, confidentiality should not discourage the

investors equal access to information); Brudney, Insiders, Outsiders, and Informational Advantages Under the Federal Securities Laws, 93 HARv. L. REv. 322, 353-67 (1979) (purpose of disclose-or-abstain rule is to prevent traders from using information to which others do not have lawful access); Schotland, Unsafe at Any Price: A Reply to Manne, Insider Trading and the Stock Market, 53 VA. L. REv. 1425, 1446 (1967) (market regulated to ensure reasonably equal access to information preferable to one of unequal access, even though the former may lead to sharper changes in price).

71. SEC v. Texas Gulf Sulphur Co., 401 F.2d 833, 854 (2d Cir. 1968) (en banc), cert. denied, 394 U.S. 976 (1969). Thus, someone holding secret information should not act on it "until the news [of it] could reasonably have been expected to appear over the media of widest circulation." Id.

72. See 5 A. Scort, supra note 50, at $3564-67$ (discussing examples of fiduciary's breach); id. at 3574-76 (explaining recovery of delinquent fiduciary's profits).

73. This showing of access implies a scienter requirement, and defendant could plead lack of knowledge as an affirmative defense. However, knowledge of the confidentiality of information may reasonably be inferred from a position of special access. It seems reasonable to expect a government employee who has special access to information to know that the information he sees is confidential. Only in an unusual case could an employee defend successfully on the ground that he believed information to be publicly available when in fact it was not.

74. Special authorization of certain outsiders to see government information would not publicize information sufficiently to release it from protection of the fiduciary duty. In some instances, the government may need private expertise, but it should not necessarily have to sacrifice the confidentiality of its information to do so. Cf. 18 U.S.C. $\S$ 207(f) (Supp. III 1979) (creating exception in Title $V$ for communication of scientific or technological information).

75. Thus personal information about government officials, which might be important to a business in deciding how to approach an agency, would not be protected by the 
use of personal knowledge and skills. Government employees should not be barred from using ideas they developed during government service if nongovernment people could have reached the same conclusions. Former public servants, therefore, should have an affirmative defense that they used information that was or reasonably could have been derived from available information.

The meaning of confidentiality in this context must also conform to statutes governing the use of confidential information. Information protected by the Privacy Act ${ }^{76}$ and other non-disclosure laws should have the protection of the fiduciary duty, but information made public, even if in apparent violation of those laws, should not. Because a former employee should not be prevented from using information that anyone else may use, the fact of dissemination should be enough to release him from his duty. On the other hand, information requested from and released by the government under the Freedom of Information Act (FOIA) ${ }^{77}$ should be made public ${ }^{78}$ and left unprotected by the fiduciary concept, ${ }^{79}$ even though broad distribution of the information or even of the request is not always likely. ${ }^{80}$

The second element of plaintiff's case, identification of profits gained, will create liability in proportion to the wrong. Plaintiff can

duty. Knowledge of how other agencies work, acquired during government service through interagency contacts, would be protected if similar contacts and similar opportunities for observation were not available to private groups.

76. 5 U.S.C. $\$ 552 \mathrm{a}$ (1976 \& Supp. III 1979). The Act regulates the release of information about individuals by federal agencies.

77. 5 U.S.C. $\$ 552$ (1976 \& Supp. III 1979).

78. See H.R. REP. No. 1497, 89th Cong., 2d Sess. 1, 11, reprinted in [1966] U.S. ConE Cong. \& AD. NEws 2418, 2418, 2429 (declaring that new government information act is, unlike its predecessor law, "a true Federal public records statute," permitting public to see all federal records with few exceptions).

79. The fiduciary doctrine's principle of equality and the ForA's principle of availability of information dictate that a former public servant should not be barred from using information that any other citizen may obtain, despite the fact that the former public servant could submit an FOIA request for information that he already has and be free to use it when it is released. Two factors, in addition to the FOIA's categories of information exempt from disclosure, see 5 U.S.C. $\$ 552(\mathrm{~b})$ (1976), should prevent the FOIA from swallowing the fiduciary concept. First, because the fiduciary doctrine protects government activities at least as much as private ones, an FOIA request will put the government on notice as to information that the private employer of a former government employee now has. Second, private businesses, the group most likely to be interested in information that competitors have, will probably take care to see what FOIA requests competitors make.

80. Although the FOIA requires agencies to publish certain information in the Federal Register, 5 U.S.C. $\$ 552(a)(1)(1976)$, and make other information "available for public inspection and copying," id. $\$ 552(a)(2)$, they will supply other information only in response to a specific request, $i d$. $\$ 552(a)(3)$, and there is no provision for making these requests known. 
recover to the extent that the profit resulted from the breach. ${ }^{81}$ Frequently, confidential information will be combined with other information, in which case plaintiff can recover a part of the proceeds equal to the proportional contribution of the confidential information. ${ }^{82}$ Determining exact proportions should be left to the trier of fact. ${ }^{83}$

Recovery from a third party will require demonstration that the party had actual or constructive notice ${ }^{84}$ of the breach of duty ${ }^{85}$ This standard would cover cases where third parties can avoid or prevent breaches of duty, but would eliminate much of the disincentive to deal with former government employees for fear that a breach of fiduciary duty might be involved. An employer, the typical third party in government fiduciary cases, should know an employee's previous position in government and should recognize the general types of information he would have handled. Therefore, when an employee communicates either facts of that general type that are unknown to the employer, or a theory that could be based only upon such facts, the

81. Cf. SEC v. Texas Gulf Sulphur Co., 312 F. Supp. 77, 90-97 (S.D.N.Y. 1970), aff'd, 446 F.2d 1301, 1307-08 (2d Cir.), cert. denied, 404 U.S. 1005 (1971) (placing all profits from trading on inside information in escrow fund for investors); 5 A. Scotr, supra note 50 , at 3574-76 (discussing cases where profits of corporate fiduciaries were recovered).

82. See 5 A. Scort, supra note 50 , at $3642-44$ (plaintiff entitled to pro rata share of wrongdoer's property obtained after mingling plaintiff's property with his own); RESTATEMENT OF RESTITUTION $\$ \$ 210,214$ (1936) (share of property or reimbursement of value of thing taken).

83. No sophisticated calculations should be necessary. Similar decisions are required in comparative negligence jurisdictions, and because those decisions may be regulated by general guidelines, similar apportionments in fiduciary cases should be possible without producing erratic judgments. See V. Schwartz, Comparatrve Negligence 278-79 (1974) (suggesting comparative negligence guidelines); cf. Note, Comparative NegligenceA Survey of the Arkansas Experience, 22 ARk. L. REv. 692, 707 (table 7) (1969) (survey of state lawyers indicates shift from contributory to comparative negligence rule generally did not make liability and damages more difficult to explain to juries).

84. For a discussion of the requirements for constructive notice, see note 57 supra. The principles of agency apply to notice, RESTATEMENT of REsTitution $\$ 174$, Comment d (1936); 4 A. ScoTr, supra note 50, at 2427-28, so that a private business employee's awareness of another employee's breach of duty to the government may be imputed to the business.

85. A third party who receives fruits of the breach of a duty is liable if he purchased them with notice of the breach or if he obtained them gratuitously, regardless of notice. Restatement of Restitution $\$ 201$ (1936); 5 A. Scotr, supra note 50, at 3568-71. In government fiduciary cases, third parties, particularly private employers, should be treated as purchasers with notice for several reasons. First, employers do hire former public servants and can hardly be donees of information. Second, the notice requirement will not impose liability by surprise on employers and thus not discourage the hiring of former government employees. Third, purchasers with notice are fully ac. countable for profits gained with wrongfully acquired property, RESTATEMENT of RESTITution $\$ 201$ (1936); $5 \mathrm{~A}$. Scorr, supra note 50, at 3570, 3605, while donees are liable only for the value of the property, REsTATEMENT of Restitution $\$ 204$, Comment $d$ (1936); 5 A. Scort, supra note 50, at $3606-07$, although this distinction may not apply to confidential information, which sometimes can be valued only by the profits it produces. 
employer should understand that he may be receiving confidential information..$^{86}$ An employer could not be held accountable for using theories that might reasonably be based upon his own or other public information because he would expect those theories to be freely usable.

\section{Rights of Action}

Effective implementation of the fiduciary doctrine requires that both the government and private parties have rights of action. ${ }^{87}$ Suits would be non-statutory, based on a federal common law of obligations to the federal government. ${ }^{88}$ Government suits would be in equity,

86. A private employer could erect a rebuttable presumption of non-liability by adopting certain screening procedures to prevent employees who used to work for the government from transmitting government information to other people or areas in the firm. The practice of some law firms offers a rough analogy: they may in some cases screen former government attorneys to avoid disqualification as a firm under DR 5105(D) of the ABA Code of Professional Responsibility. See Kesselhaut v. United States, 555 F.2d 791, 792-93 (Ct. Cl. 1977) (firm erected sufficient barriers to exclude former public official from participation in case); cf. Armstrong v. McAlpin, 606 F.2d 28, 33-34 (2d Cir. 1979), rev'd on other grounds, 625 F.2d 433 (2d Cir. 1980) (en banc) (discussing factors affecting sufficiency of screening). Screening under the fiduciary doctrine provides only a rebuttable defense, however, because liability accrues when information is actually used, not when there is merely access to information.

87. This Note proposes private rights of action different from the citizens' action recommended in Kalo, supra note 5, at 1595-1608. Although the rights suggested here could co-exist with Kalo's proposal, use of the rights here, if extended to cover present employees as well, see note 96 infra, should make Kalo's citizens' action unnecessary. Recoveries by plaintiffs under the theories of this Note should provide an incentive at least as great as the attorneys' fees award that Kalo suggests for his plaintiffs. Furthermore, this Note's plaintiffs will generally be the defendants' competitors and will tend to watch for the defendants' violations, while Kalo's plaintiffs will not be inclined to be observant. Kalo's theory also contains two implementation problems that the traditional equity and tort remedies offered by this Note avoid. First, to overcome the standing problem, the citizens' action requires statutory authorization. See Schlesinger v. Reservists Comm. to Stop the War, 418 U.S. 208, 224 n.14 (1973) (statute could give private citizens standing otherwise lacking to sue public officials for conflict of interest). This step will delay implementation and expose the proposal to limiting amendment. Second, Kalo's action requires a preliminary hearing to determine plaintiff's competence to sue, Kalo, supra note 5, at $1600-08$, that will prolong litigation. At this hearing, the government may challenge plaintiff's right to sue, $i d$. at 1600-04, which will force the court to examine whether the wrong alleged is legal or political, thus opening many difficult problems of justiciability. See generally P. Bator, P. Mishkin, D. Shapiro, \& H. Wechsler, Hart and Wechsler's The Federal Courts and the Federal System 233.41 (2d ed. 1973) (discussing political question doctrine).

88. Federal common law exists where federal interests require a uniform national rule. Such interests arise when a transaction implicates federal legislative or constitutional policies or when the federal government is treated as a legal entity requiring rights and obligations consistent throughout the states. See Clearfield Trust Co. v. United States, 318 U.S. 363,367 (1943) (desirability of uniform national rule means federal common law controls paper issued by federal government); United States v. Kearns, 593 F.2d 729, 732 (D.C. Cir. 1978) (using interest analysis to find that federal common law controls fiduciary duty owed by present employee to federal government); Friendly, In Praise of Erie-And the New Federal Common Law, 39 N.Y.U. L. REv. 383, 408-21 (1964) (discussing areas governed by federal common law).

Federal courts will have jurisdiction both of government actions, see 28 U.S.C. $\$ 1315$ 
while private suits might lie in either equity or tort, depending on plaintiff's own involvement with the information used.

The government is not always allowed to bring a non-statutory suit in equity, ${ }^{89}$ but two theories of non-statutory actions support the validity of suits founded on the fiduciary doctrine. First, the government has a cause of action when a private citizen would in an analogous situation, ${ }^{90}$ and the fiduciary doctrine has traditionally regulated private relationships. Second, the federal government may sue without a statute if the suit promotes constitutional powers ${ }^{11}$ or legislative policies. ${ }^{92}$ The equitable actions proposed here would enable the executive to enforce its power to command loyalty from its employees $^{93}$ and to improve integrity and efficiency in government, goals of the Ethics in Government Act.94 Title V does not interfere with the government's right of action because to restrict an equitable right, a statute must set forth an explicit limitation, ${ }^{95}$ which Title $V$ does not do.

(1976) (United States as plaintiff), and of private actions, see 28 U.S.C. $\$$ 1331(a) (1976) (federal question; amount in controversy must exceed $\$ 10,000)$; cf. People Versus Porn v. Nixon, 465 F. Supp. 340 (N.D. Cal. 1978) (suit against former President for breach of fiduciary duty to federal taxpayers properly removed to federal court in part because action raised question of duty of federal officer).

89. See New York Times Co. v. United States, 403 U.S. 713, 718.19 (1971) (Black, J., concurring) (in absence of congressional authorization, courts will not issue injunction on alleged national security grounds to halt newspaper publication of government information); id. at 723 (Douglas, J., concurring) (same); id. at 730 (Stewart, J., concurring) (same); $i d$. at 732, 740 (White, J., concurring) (same); id. at 741-47 (Marshall, J., concurring) (same); cf. United States v. Standard Oil Co., 332 U.S. 301, 313-17 (1947) (refusing to create new common-law liability in tort for injury to American soldier).

90. See, e.g., United States v. California, 332 U.S. 19, 26-29 (1947) (permitting right of action to protect proprietary interest in submerged lands); Cotton v. United States, 52 U.S. (11 How.) 229 (1850) (implying right of action for trespass).

91. See, e.g., Wyandotte Transp. Co. v. United States, 389 U.S. 191, 201-06 (1967) (basing right of action on national power over interstate commerce).

92. See, e.g., United States v. Glaxo Group Ltd., 410 U.S. 52, 57-60 (1973) (holding that interest in integrity of patents gives United States standing); $c f$. United States v. Mfoore, 340 U.S. 616, $619-20$ (1951) (power of court of equity to protect public interest fully under Housing and Rent Act enabled it to grant government's request for restitution order); Porter v. Warner Holding Co., 328 U.S. 395, 400 (1946) (similar result under Emergency Price Control Act).

93. This power might be inferred from statute, 3 U.S.C. $\$ 301$ (1976) (delegation of Presidential functions), or from the Constitution, U.S. Consr. art. II, $\$ 3$, cl. 4 ("[the President] shall take Care that the Laws be faithfully executed"). Effective delegation and faithful execution rest on the loyalty of government employees, whose duties include maintaining the confidentiality of government information.

94. See SENATE REPORT, supra note 15 , at 4247 ("Honest government, and decisions made in an impartial manner, are the objectives of this Title."); $c f$. United States v. Mississippi Valley Generating Co., 364 U.S. 520, 563-66 (1961) (giving equitable relief not specifically authorized by conflict of interest statute in order to promote policies of statute).

95. See United States v. United Mine Workers, 330 U.S. 258, 272 (1947) (applying "old and well-known rule that statutes which in general terms divest pre-existing rights or privileges will not be applied to the sovereign without express words to that effect"). Legal remedies must also be inadequate in order for an action in equity to lie, see, e.g., 
The plaintiff in fiduciary actions typically would be the government because the duty breached, that of maintaining the confidentiality of information in government hands, is one owed through an employment relationship. Nevertheless, information about the postemployment activities of former public servants and incentives to sue for wrongful acts would often be shared by the government and the competitors of the former servant's new employer. Those competitors presumably would detect the use of information that the government had obtained from them and would perceive any competitive advantage that the private employer gained through the use of the information.

In two types of cases, therefore, private parties should be able to sue other private parties ${ }^{96}$ for the improper use of confidential government information. ${ }^{97}$ First, a private right of action similar to the government's should arise where private use is made of information that had been sent to the government on the understanding that it would be kept confidential. The former employee who profited from that information owed a duty of confidentiality both to the government and to the private source, and both should be able to sue.98

H. McClintock, supra note 55, at 98-99, 103.05, but it is clear that current law does not adequately address the problem of delinquent fiduciaries to the government. See pp. 195 . 99 supra.

96. Private suits should be able to reach abuses of information involving current as well as former government employees. The fiduciary duty violated is the same, and the private plaintiff suffers the same injury whether the public servant causing it is still employed by the government or not.

97. Such actions may be founded on a theory that anyone whom a rule of law is designed to protect may sue when wronged by a violation of that law. This theory parallels the theory of private rights arising under statutes and the Constitution. See, e.g., Cort v. Ash, 422 U.S. 66, 78 (1975) (statutory action by member of class "for whose especial benefit the statute was enacted") (quoting Texas \& Pac. Ry. v. Rigsby, 241 U.S. 33, 39 (1916)); Bivens v. Six Unknown Named Agents of Fed. Bureau of Narcotics, 403 U.S. 388, 390-97 (1971) (action for damages where Fourth Amendment rights are violated). Cort also includes other tests for legislative intent and consistency with the legislative scheme in order to determine whether a private right of action exists. These tests are peculiar to statutory rights, but rest on the broader question whether the policy of the law justifies a private suit.

Much of the discussion in cases such as Cort and Bivens focuses on whether the right of action is federal rather than state. Private suits alleging breaches of a federal fiduciary duty are clearly appropriate for federal adjudication. At the core of any private suit would be whether the defendant violated a duty to the federal government. This implication of a right possessed by the federal government, see, e.g., Bank of Am. Nat'I Trust \& Sav. Ass'n v. Parnell, 352 U.S. 29, 33-34 (1956) (suggesting federal common law will control private litigation that "touch[es] the rights and duties of the United States"); American Pipe \& Steel Corp. v. Firestone Tire \& Rubber Co., 292 F.2d 640, 643-44 (9th Cir. 1961) (federal common law controls subcontract between private parties under government contract because national rule needed), indicates that federal courts rather than state courts should decide the cases. Federal jurisdiction would also be appropriate so that uniform rules concerning the duty could be developed. See note 88 supra.

98. Enforcement of the fiduciary duty will impose an additional task on the Department of Justice, which has limited resources for prosecuting claims. This constraint, to- 


\section{Ex-Government Employees}

Second, a right of action should accrue to a private party who has been injured by the use of confidential government information, ${ }^{99}$ regardless of the source of the information. Although an agent is not always liable in tort to a third party for breach of duty to his principal, ${ }^{100}$ such liability should exist here because the duty of former government employees to keep information confidential is higher than that of agents in the private sector. ${ }^{101}$ Both the obligation to the public that inheres in government employment and the public policies that require the maintenance of confidentiality raise the level of the duty owed to the government. The importance of this duty to the government in turn increases the need for enforcement of the duty. Private suits would fill the enforcement gaps that a government with limited resources inevitably leaves.

\section{Advantages of the Doctrine}

The broad reach and flexible sanctions of the fiduciary doctrine enable it to avoid the problems of limited scope and defective penalties that Title V presents. Despite its lack of "bright-line" rules, the doctrine still possesses the clarity necessary for employees and judges to understand it.

\section{Breadth of Scope}

The concept of a fiduciary duty is better tailored to reach problematic post-employment activities than are the Title $V$ rules because an action for breach of the duty is more responsive to individual factual settings. The contours of the duty do not depend on per se rules; rather, whatever confidential information an employee gained

gether with political pressures and concerns about the possible undesirable effects of fiduciary suits, might tend to discourage suits by the government. See, e.g., Kalo, supra note 5, at 1586-87 (speculating why government brings so few fiduciary suits). Private suits will free enforcement of the fiduciary duty from such inhibitions. Cf. J.I. Case Co. v. Borak, 377 U.S. 426, 432 (1964) (private right of action under $\$ 14$ (a) of Securities Exchange Act of 1934 provides "necessary supplement" to action by SEC, which has little time to find violations in proxy materials).

99. These damage actions would be in tort rather than in equity because there would be no duty of confidentiality with respect to the plaintiff's information; the plaintiff, therefore, would have to show actual injury. Losses would fall into two categories: loss of something already possessed and loss of something the plaintiff would have had if the defendant had not used confidential government information. The former category of injuries should be easy to measure, but the latter, which will include cases of bidding for government contracts, will not: the plaintiff will have to show the substantial likelihood that he would have possessed the thing had the defendant not improperly used government information.

100. See Restatement (SECOND) of Agency $\$ \S 352-354$ (1957).

101. See note 62 supra. 
while with the government would determine the scope of his fiduciary duty. No advantage would attach to positions that give access to information but that fall outside Title V restrictions, ${ }^{102}$ and no liability would discourage the free use of information when there is no abuse of confidentiality. As a result, the fiduciary duty doctrine should not present the disincentives that impair the Title $\mathrm{V}$ rules. The doctrine would discourage only those who hope to obtain confidential information for their own use, exactly the effect that a rule designed to promote equal opportunity to use information should have.

Use of the fiduciary doctrine would also avoid a lack of clarity ${ }^{103}$ that could discourage public service ${ }^{104}$ or impede the efficient use of information. It is true that Title V's "bright-line" rules may be clearer than the proposed doctrine, ${ }^{105}$ which is tied to the less fixed standards ${ }^{106}$ that govern decisions as to the confidentiality of information. Furthermore, the content of the fiduciary duty would vary in individual cases because of different degrees of access to and willingness to use confidential information. On the other hand, no one appears to have questioned the clarity of the fiduciary doctrine as applied in the private sector, ${ }^{107}$ and guidelines could, in any event, be set to clarify its scope in the public context. ${ }^{108}$ In addition, two other qualities of the standard should minimize any undesirable deterrent effects. First, the burden for understanding the rule would rest on government employees, ${ }^{109}$ who are in the best position to know whether

102. Thus, for example, a staff assistant who sees work produced elsewhere that his chief must approve will be barred from using confidential information contained in it. By contrast, the elements of Title $V$ that require official responsibility and personal and substantial participation do not reach people with such access. See p. 196 supra.

103. An unclear rule would have two opposite effects. First, for the risk averse, it would deter legitimate behavior felt to approach the line of wrongdoing. Second, for those not averse to risk, a vague rule might seem to increase the possibility of nonenforcement and thus increase the incentive to break the rule. See R. Posner, Economic ANalysis of Law 424-25 (2d ed. 1977).

104. See United States v. Conlon, 26 CRIM. L. REP. (BNA) 2201, 2202-03 (D.D.C. Oct. 26, 1979) (construing conflict of interest statute narrowly to avoid vagueness and disincentive to government service that vagueness creates).

105. But see N.Y. Times, Mar. 16, 1979, $\S A$, at 30 , col. 1 (editorial criticizing Ethics in Government Act as vague).

106. Those standards contrast with Title V, whose restrictions are limited to cases involving contact, prior participation, particular matter, and, in some instances, time. See pp. 195-97 supra.

107. This absence of criticism may indicate that judges apply widely held notions of what the fiduciary doctrine should include. Implementation of the duty is left up to the judge in equity, who acts according to the principles established by prior decisions in equity, see H. McClintock, supra note 55 , at $51-52$ (judge does not have personal discretion in equity but bases decisions on established principles), which are supposed to represent decisions of conscience.

108. See pp. 202-06 supra (suggesting such guidelines).

109. Employer liability puts some burden on a third party as well, but that burden should be limited to a good faith effort to isolate pockets of confidential information 


\section{Ex-Government Employees}

they are using confidential information. ${ }^{110}$ Second, the doctrine possesses the clarity of a "reasonableness" standard: cases would not be judged arbitrarily, but in accordance with objective standards as to what uses of information are unfair. ${ }^{111}$

\section{Appropriate Sanctions}

The variety of equitable sanctions available under a fiduciary duty standard could be used to tailor a response to fit the particular breach of duty, ${ }^{12}$ thereby avoiding Title V's sanctioning and enforcement problems. Recovery of ill-gotten gains would extract from the defendant, whether former employee or third-party employer, ${ }^{113}$ exactly

possessed by an employee. The government's ability to grant permission to use information should be an incentive for an employer to make such an inquiry. Furthermore, the employer would be liable only when the former public servant is personally liable; such personal liability should discourage the employee from using confidential information in the first place.

110. Employees know most easily and most cheaply when an abuse might occur and are in the best position to stop it. Placing the burden on them is consequently the most efficient way of implementing the fiduciary duty. Cf. G. Calabresi, The Costs of AcCIDENTS 69-94, 135-73, 312 (1970) (discussing imposition of burdens in tort on cheapest cost avoider).

111. Clarity of a rule functions both to guide judges in decisions and to regulate individual conduct. See Note, The Void-For-Vagueness Doctrine in the Supreme Court, 109 U. PA. L. REv. 67, 81, 89.96 (1960) (concluding that Supreme Court invalidates state statutes as unconstitutionally vague in part because federal courts must have clear indication of what state law is). A judge has greater freedom to interpret the fiduciary doctrine to reach just results than to modify statutory rules; this diminishes the doctrine's need for clarity relative to the need of a statute such as Title $V$. Moreover, the judicial ability to resolve cases according to the principles of equity reduces the need for precision because socicty's norms of just behavior inform those principles. Cf. Nash v. United States, 229 U.S. 373, 376-78 (1913) (common law frequently requires individuals to estimate conduct against reasonableness of jury); Waters-Pierce Oil Co. v. Texas, 212 U.S. 86, 109-10 (1909) (state antitrust statute barring activities "reasonably calculated" to limit trade or fix prices not unconstitutionally vague).

112. Tailoring makes penalties proportional to the crime, which lends a sense of retributive justice to a society's regime of punishments: greater wrongs should be penalized more than lesser wrongs. See H. Harr, Punishment and Responsibility 233-34 (1968). Proportionality can also be considered in utilitarian terms of deterrence. To the extent that the benefits of a wrong are weighed against the likelihood of capture and the severity of punishment, properly tailored and consistent penalties deter the commission of wrongs precisely to the extent society wishes them deterred. Disproportional penalties will fail to do this and may also undermine public respect for the law. Note, Disproportionality in Sentences of Imprisonment, 79 Colum. L. Rev. 1119, 1121 n.12 (1979). The goal of deterrence in any individual case may require a disproportional sentence, however. H. Packer, The Limits of the Criminal Sanction 139-45 (1968).

113. Sce, e.g., Hunter v. Shell Oil Co., 198 F.2d 485, 489-90 (5th Cir. 1952) (imposing constructive trust on oil lands held by third party business associates who had acquired lands on basis of plaintiff's confidential information); United States $v$. Mahaney, $27 \mathrm{~F}$. Supp. 463 (N.D. Cal. 1939) (enjoining third party client from using confidential SEC information). 
the amount of his wrongful benefit. ${ }^{114}$ The stigma of a criminal conviction would not attach to a wrongdoer and would not discourage prosecutors, ${ }^{115}$ but forced restitution would destroy any incentive to violate the duty. In addition, a fuller range of remedies would be available when appropriate: compensatory damages when there was injury, ${ }^{116}$ exemplary damages ${ }^{117}$ for intentional egregious breaches, ${ }^{118}$

114. A delinquent fiduciary to the government must account for, or become constructive trustee of, his profits. E.g., United States v. Carter, 217 U.S. 286, 306, 317-18 (1910); United States v. Bowen, 290 F.2d 40, 44.45 (5th Cir. 1961); United States v. Drisko, 303 F. Supp. 858, 860-61 (E.D. Va. 1969).

115. See United States v. Conlon, 26 CRIM. L. REP. (BNA) 2201, 2202-03 (D.D.C. Oct. 26, 1979) (noting congressional hesitation to stigmatize activities in the murky field of conflicts of interest); cf. note 44 supra (citing government reluctance to prosecute).

116. See, e.g., United States v. Bernard, 202 F. 728, 731-32 (9th Cir. 1913) (compensatory damages part of incidental relief that court of equity may give).

117. Traditionally, a court of equity has been unable to award exemplary damages. See id. at 732 (punitive damages beyond competence of equity court). A minority of states now take the opposite view, however, on the theory that the disability arises out of the jurisdictional separation of law and equity, which the merger of those courts removes. The power to award exemplary damages is, in their view, discretionary with the court, dependent upon some showing of intent or malice. See, e.g., Starkovich v. Noye, 111 Ariz. 347, 350-52, 529 P.2d 698, 701-03 (1974) (fraud); Charles v. Epperson \& Co., 258 Iowa 409, 431-32, 137 N.W.2d 605, 617-18 (1965) (intentional fraud); I.H.P. Corp. v. 210 Central Park South Corp., 12 N.Y.2d 329, 332-33, 189 N.E.2d 812, 813-14, 239 N.Y.S.2d 547, 548-49 (1963) (malice). In order for federal courts to craft appropriate equitable remedies for breach of fiduciary duty to the government, it is important that they be able to award exemplary damages, in accord with the minority state view. Because the fiduciary doctrine would be part of federal common law, see note 88 supra, forum state decisions should not be controlling. It may be necessary, however, to imply a materiality requirement when exemplary damages are sought because it has been said that such damages will be awarded only when there is a sufficient injury. See Starkovich v. Noye, 111 Ariz. 347, 351-52, 529 P.2d 698, 702-03 (1974) (discussing sufficiency of equitable relief or compensatory damages to support award of punitive damages); $c f$. International Bankers Life Ins. Co. v. Holloway, 368 S.W.2d 567, 584 (Tex. 1963) (actual harm to plaintiff one factor in making award of exemplary damages). But see United States v. Snepp, 595 F.2d 926, $937-38$ (4th Cir. 1979), rev'd on other grounds, 444 U.S. 507 (1980) (punitive damages may be awarded even if compensatory damages are nominal).

118. Exemplary damages punish and deter. They would therefore provide an effective device for enforcing the fiduciary doctrine insofar as the restorative function of a constructive trust might leave some incentive to violations. Punitive damages are left in the discretion of the trier of fact so that they may be granted if the wrong seems to require greater punishment or deterrence than regular damages or equitable relief can give. For example, some former public servants might calculate that it is profitable to breach their duty to the gorernment because they can lose no more than their wrongful profits and because the probability of successful prosecution is less than one. Punitive damages are aimed precisely at such calculations, and should be awarded when such intention is clearly inferable from the circumstances. See Charles v. Epperson \& Co., 258 Iowa 409, 432, 137 N.W.2d 605, 618 (1965) (awarding exemplary damages because com. pensatory damages insufficient to deter intentional fraud); International Bankers Life Ins. Co. v. Holloway, 368 S.W.2d 567, 584 (Tex. 1963) (unconscionable conduct warrants award of exemplary damages as deterrent).

Even without punitive damages, a successful suit will subject the defendant to the moral opprobrium of the community, an additional sanction that may have some effect. Cf. H. PACKer, supra note 112 , at $42-43$ (social disgrace part of threat of criminal punishment that gives it deterrent effect); E. Sutherdand, White Collar Crime 245-56 (1949) 


\section{Ex-Government Employees}

and injunctions to prevent future violations. ${ }^{119}$ This array of remedies should enable a court effectively to enforce the fiduciary doctrine.

A breach of duty suit would also reduce the threat of inconsistent enforcement ${ }^{120}$ that arises from Title V's focus on government contacts. Because the fiduciary obligation reaches situations other than appearances before or communications with departments or agencies, reports of violations could be expected to come from outside sources in addition to interested government servants. Competitors suspecting wrongful conduct would complain to the government. Furthermore, enforcement would not depend entirely on government willingness to sue. Even when the government might have little incentive, misuse of a private party's information (supplied to the government) or misuse injuring a private party would give rise to a private right of action.

\section{E. Discovery and Harassment}

Although private suits for breach of fiduciary duty to the government might raise problems of harassment or abuse of discovery, courts are equipped to forestall such tactics. Discovery could defeat the purposes of the fiduciary duty in several ways. First, the possibility of discovery might tempt businesses to sue competitors in order to acquire their confidential information, regardless of the grounds for suit. Protective orders, however, are available to prevent the acquisition and use of information outside of litigation, and courts should issue such orders when appropriate. ${ }^{121}$ In addition, discovery in private suits might, in seeking to establish the confidentiality of government information,

(isolation of business from criticism of "public agencies of communication" and public's difficulty in understanding complex business arrangements allows white collar crime to flourish). The possibility of private suits should also increase the likelihood of enforcement and reduce the temptation to violate the duty.

119. See, e.g., United States v. Mahaney, 27 F. Supp. 463 (N.D. Cal. 1939) (enjoining use of confidential SEC information).

120. Prosecution of breach of duty suits might take more time and require the participation of more people than the administrative enforcement mechanism in Title $V$. Recovery of defendants' profits should offset many of these added costs. Even if it does not, however, equitable suits are still preferable because their advantages would outweigh any slight increase in costs.

121. FED. R. Civ. P. 26(c) authorizes courts to issue protective orders "which justice requires to protect a party or person from annoyance, embarrassment, oppression, or undue burden or expense. . . Confidential information may be protected, see FED. $R$. CIv. P. 26(c)(7) ("a trade secret or other confidential research, development, or commercial information"), so that it is used only in litigation. The moving party must demonstrate that disclosure of alleged confidential information "will work a clearly defined and very serious injury." United States v. IBM Corp., 67 F.R.D. 40, 46-47 (S.D.N.Y. 1975). Courts have the ability to issue particularized orders, see, e.g., Scovill Mfg. Co. v. Sunbeam Corp., 61 F.R.D. 598, 602 (D. Del. 1973) (restricting availability of information to discovering party's trial counsel), and should accordingly protect information in fiduciary suits. 
also disrupt the operations of the government. Discovery that violates privileges surrounding certain types of government information would be prohibited. ${ }^{122}$ Finally, although the government usually cannot prevent discovery simply on the ground of burdensomeness, ${ }^{123}$ courts should restrict the manner or scope of discovery so that it is as convenient as possible. ${ }^{124}$ The discovering party also might have to bear some of the costs of discovery. ${ }^{125}$

Private fiduciary suits might also seem to offer a means for businesses to harass competitors. To prevent such abuses of litigation, plaintiffs who brought harassment suits should be liable for defendants' attorneys' fees and expenses. ${ }^{126}$ Liability would not arise when a suit was merely unsuccessful, ${ }^{127}$ but the fiduciary standard would be simple enough to recognize that groundless suits would be dismissed at an early stage. ${ }^{128}$ As a result, nonmeritorious suits designed

122. See, e.g., United States v. Reynolds, 345 U.S. 1, 10-11 (1953) (military secrets); Republic of China v. National Union Fire Ins. Co., 142 F. Supp. 551, 556-57 (D. Md. 1956) (diplomatic secrets). Information reflecting government decisionmaking processes is also protected so that the candor necessary to full deliberation is not inhibited, see, e.g., Carl Zeiss Stiftung v. V.E.B. Carl Zeiss, Jena, 40 F.R.D. 318, 324-26 (D.D.C. 1966), aff'd per curiam, 384 F.2d 979 (D.C. Cir.), cert. denied, 389 U.S. 952 (1967) (protecting Justice De. partment documents), but this consideration may be outweighed by litigants' need for information about government decisions, see Pierson v. United States, 428 F. Supp. 981, 395-96 (D. Del. 1977) (where records of IRS decision to revoke letter ruling were of "greatest need" to plaintiff and "most relevant" to judicial review, balance of discovery policies heavily in favor of disclosure).

123. See, e.g., Culp v. Devlin, 78 F.R.D. 136, 140 (E.D. Pa. 1978) (need for information justified discovery despite great burden imposed on government).

124. See, e.g., United States v. IBM Corp., 60 F.R.D. 650, 652-53 (S.D.N.Y. 1973) (framing protective order so that United States need not search its files again); Colonial Capital Co. v. General Motors Corp., 29 F.R.D. 514, 518 (D. Conn. 1961) (limiting plaintiffs to written interrogatories of chief of defendant corporation in order to save his time); Haymes v. Columbia Pictures Corp., 16 F.R.D. 118, 123 (S.D.N.Y. 1954) (requiring parties to agree on convenient deposition schedule).

125. See Moore v. George A. Hormel \& Co., 2 F.R.D. 340, 342 (S.D.N.Y. 1942) (rule authorizing court to frame discovery orders as justice requires permits court to order discovering party to pay some discovery expenses).

126. Although the "American Rule" holds that each party bears his own fees and expenses, a losing party who acts in bad faith will be liable to his opponent for fees and expenses. See, e.g., Alyeska Pipeline Serv. Co. v. Wilderness Soc'y, 421 U.S. 240, 247-59 (1975). Harassment, delay, or other litigation abuses constitute bad faith supporting an award of fees and expenses. See, e.g., Nemeroff v. Abelson, 469 F. Supp. 630, 639.40 (S.D.N.Y. 1979), rev'd on other grounds, 620 F.2d 339 (2d Cir. 1980) (making award where suit brought to damage reputation and credibility of writer and publisher).

127. See, e.g., Browning Debenture Holders' Comm. v. DASA Corp., 560 F.2d 1078, 1088 (2d Cir. 1977) (rule exists so that plaintiffs "with colorable, albeit novel, legal claims would [not] be deterred from testing those claims in a federal court.")

128. Defendants will have to police their own interests in halting groundless suits. Lack of an early protest may indicate that a claim is not entirely bad. See id. at 1088 (conclusion that claim against one defendant for breach of fiduciary duty was colorable and not in bad faith enhanced by fact that defendant did not move to dismiss until eve of trial). 
to force defendants to settle rather than to bear the burden of trial would be unlikely to occur. ${ }^{129}$

\section{Conclusion}

The concept of a fiduciary duty to the government offers a remedy for the misuse of confidential government information by former public employees. Current and former public employees are under a duty to maintain the confidentiality of government information; if they breach that duty, they and knowledgeable third parties who benefit from the breach should be accountable for their profits and for other damages. Breach of the duty may injure either the government or a private party, and both should have a right of action. Only such a scheme of rights will guarantee equal access to and equal treatment by the government, while enabling the government to operate fairly and effectively.

129. Furthermore, the requirements for standing-use of the plaintiff's information or use of government information to the plaintiff's detriment-generally restrict the class of plaintiffs to the defendant's competitors; competitors, however, would be unlikely to bring such suits for two reasons. First, particularly in industries highly regulated by the government, potential plaintiffs will have their own former public servants and so will themselves be vulnerable to suit. They should be hesitant to start such litigation without reason. Second, business competitors will not be judgment-proof and so will have something to lose if fees and expenses are awarded. The incentive that judgmentproof status gives plaintiffs in other types of litigation to sue hoping to force settlements, see, e.g., Cohen v. Beneficial Indus. Loan Corp., 337 U.S. 541, 548-49 (1949) (discussing state attempts to eliminate "strike suits" brought by shareholders who have little stake in outcomes), is absent here. 